\title{
DETECTION OF AKABANE VIRUS GENOME IN ORGANS AND BLOOD OF EXPERIMENTALLY INFECTED CAVIES
}

\section{E.G. NIKITINA, N.I. SALNIKOV, S.A. KATORKIN, E.A. BALASHOVA, S.ZH. TSYBANOV, D.V. KOLBASOV, A.V. LUNITSIN}

All-Russian Institute of Veterinary Virology and Microbiology, Russian Academy of Agricultural Sciences, Pokrov, Petushinskii Region, Vladimir Province, 601120 Russia, e-mail vniivvim@niiv.petush.elcom.ru, lenok.nikitina2010@yandex.ru

Received March 31, 2014

\section{Abstract}

Akabane disease, a transmissible pathology of cattle, sheep and goats, is caused by Simbu serotype virus (Bunyaviridae) and results in significant economical losses due to abortions, unviable and abnormal calves, or dead embryos and calves born. The Akabane disease epizooties, characterized by geographic locations and the coincidence with definite seasons, are widely registered. For preparative accumulation of Akabane virus the 1-2 day mice are used as the most sensitive system for Bunyaviridae isolation. Earlier we reported the development of a test system for Akabane virus RNA indication by real time reverse transcription PCR. Its efficacy was approved using infected mice and cell cultures. Furthermore, it was of interest to estimate this test system with respect to more wide range of model animals to be involved in the study and reproduction of Akabane virus. In this investigation, healthy cavies $(n=20$, the animal weight of $400 \mathrm{~g})$ were infected with a concentrated viral culture (B8935 strain) of $7.0 \mathrm{lg} \mathrm{TCID}_{50} / \mathrm{cm}^{3}$. In blood the Akabane virus RNA was detected in four animals only 4 days after inoculation, but not shown in the rest probes, which were sampled from 2 to 6 days, and one cavy died a day after infection, probably due to nonspecific reaction as the Akabane virus genome was not detected in the post mortem tissue samples of all the organs of the animal tested. After 4 days the Akabane virus RNA was also indicated in brain, lung, kidney, hart and lymphatic gland. Thus, the developed test-system is effective for Akabane disease diagnosis, and the experimentally infected cavies can be the model animals used to study and produce Akabane virus preparations.

Keywords: Akabane disease, Akabane virus, cavies, Culicoides, reverse transcription polymerase chain reaction, RT-PCR, test-system.

Akabane disease, a transmissible pathology of cattle, sheep and goats, is caused by Simbu serotype virus of Bunyaviridae family. When epizooties occur the infection results in significant economical losses in livestock due to abortions, unviable and abnormal calves, or dead embryos and calves born (1-3). The disease areal is not yet finally estimated. Since 1959 Akabane disease was registered in Japan, since 1972 in Australia and New South Wales, and since 1969-1970 in Israel, Korea and Kenya (4, 5). The Akabane disease epizooties are characterized by geographic locations and the coincidence with definite seasons, particularly from August to October and also in February, occurring periodically after a few years $(1,2,6)$. The virus is transmitted by bloodsucking insects mostly from Culicoides genus, particularly C. milne and C. imicola in Africa, C. oxystoma in Japan, and C. brevitarsis and C. wadei in Australia. It also was isolated from Aedes vexans and Culex triaeniorhynchus in Japan $(6,7)$ and from Anopheles fenestus in Kenya (2-4, 8-10).

Recently there are a number of reports on Akabane virus detection worldwide (11-13). Its genetic characteristics and pathogenesis are under consideration (14) with serological and immunological research conducted (15, 16). Development of specific vaccines is also discussed $(17,18)$. Therefore, a special attention should be paid to diagnostics and indication of Akabane disease virus genome and to the test kits $(19,20)$, and also the model systems to 
be used in investigations.

For Akabane disease diagnostics different approaches are commonly used such as fluorescent antibodies, virus neutralization test, delayed hemagglutination, complement binding assay, diffuse precipitation test and enzyme-linked immunosorbent assay. Organs and tissues of aborted animals such as brain, lymphatic gland, spleen, kidney, muscles, placenta and blood, and also the blood samples from sick animals are usually tested $(2,21)$.

The 1-2 day mice, as the most sensitive system for Bunyaviridae, are usually used for isolation preparative quantity of Akabane disease virus (21).

The test system based on real time RT-PCR that we have developed allows to detect the Akabane disease virus genome in the brain probes of experimentally infected mice and in infected cell cultures $(22,23)$.

Herein we report the results of studying whether it possible to use this system for the Akabane disease virus genome indication in blood of experimentally infected cavies and also estimate the different infectious biomaterial for further use in model experiments.

Technique. For virus production the CV-1 cells were infected with Akabane disease virus strain B8935 and cultivated at $37 \pm 0.5{ }^{\circ} \mathrm{C}$ for $2-3$ days. For titration polystyrene plates with CV-1 cell monolayer in wells were used and the cytopathic effect estimated. The observations were continued for 7 days.

Healthy cavies $(n=20$, the animal weight of $400 \mathrm{~g} ; N=3)$ were infected with a concentrated viral suspension (B8935 strain) of $7.0 \mathrm{lg} \mathrm{TCID}_{50} / \mathrm{cm}^{3}$. The animals were separated into two groups. The group I was infected using $50 \mu \mathrm{l}$ of virus containing material while in the group II the dose was $500 \mu$ l.

From day 2 to day 6 after infecting the blood samples were obtained and analyzed using a developed Test system for Akabane virus RNA real time indication in RT-PCR $(3,22,23)$. Additionally, to obtain biolmaterial for further investigation the brain, lung, kidney, lymphatic and hart tissues were sampled on day 4 from animals of the group II.

Viral RNA was extracted by nucleosorption using a TRIzol LS Reagent kit (Invitrogen, Inc., USA) according to the manufacturer's recommendations $(23,24)$.

For RT-PCR a RotorGene-6000 (Corbett Research, Australia) was used as described in the instruction to the test system $(3,22,23)$.

Results. Akabane disease virus can be propagated in hen embryos and also in sucking mice as test animals in which the paralytic symptoms develop for 2-3 days as a result of brain infection. Different continues cell lines such as VNK-21 of newborn hamster kidney, VERO, HmLu-1 are also sensitive to Akabane disease virus with clear cytopathic effect 48 to 72 hours after inoculation.

As far as one of our goals was to find an appropriate model for further investigations, the cavies were chosen due to their size and weight compared to rats and mice, that allows to decrease the number of animals used for biomaterial.

The test developed and applied in this investigation is based on a real time reverse transcription PCR with designed AV d and AV u primers flanking $113 \mathrm{bp}$ fragment complementary to the nucleocapsid $\mathrm{N}$ protein gene sequence, and the $\mathrm{AV} \mathrm{z}$ probe complementary to its internal region according to TagMan technique. The test system is high sensitive at $1.5 \pm 0.5 \mathrm{lg} M \mathrm{MD}_{50} / \mathrm{cm}^{3}$ for tissue and organ assay and $1.0 \pm 0.5 \mathrm{lg} \mathrm{TCID}_{50} / \mathrm{cm}^{3}$ for cell culture.

In blood the Akabane disease virus genome was detected only 4 days after the cavies were infected (Table). One cavy died a day after infection, probably due to nonspecific reaction as the Akabane disease virus genome was not detected in the post mortem tissue samples of all the organs of the animal tested. 
Detection of Akabane disease virus genome in blood of experimentally infected cavies using developed real time RT-PCR test system

\begin{tabular}{c|cc}
\hline \multirow{2}{*}{ Days } & \multicolumn{3}{c}{ Animals } \\
\cline { 2 - 3 } & group I $(n=12)$ & group II $(n=8)$ \\
\hline 2 & - & - \\
4 & - & - \\
5 & - & - \\
6 & - & - \\
\hline C o m m e n t s. «+ or $« \rightarrow$ means detected or undetected genome, respectively. & \\
\hline
\end{tabular}

Figure 1 shows the amplification of nucleic acids extracted from blood of cavies in one of three repeated experiments.
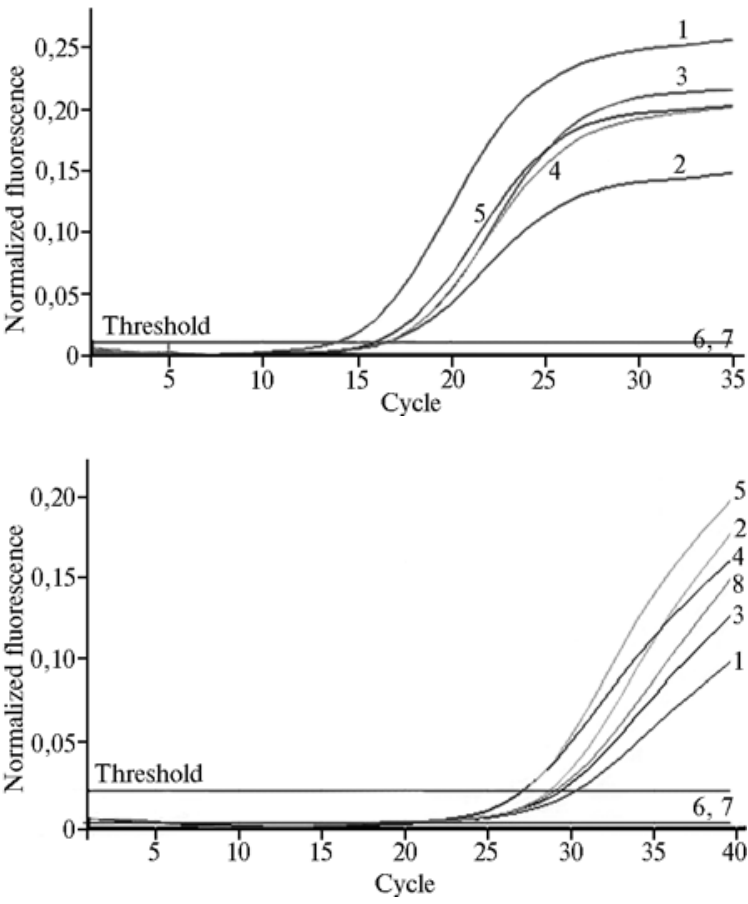

Fig. 1. Detection of Akabane disease virus in blood of experimentally infected cavies using developed real time RTPCR test system: 1 - recombinant positive control of the amplification; $2-5$ - blood of the infected animals №o $1-4$, respectively; 6 - negative extraction control; 7 - negative PCR control (4 days after experimental infection; typical results of amplification are shown).

Fig. 2. Detection of Akabane disease virus in organs and tissues of experimentally infected cavy № 4 using developed real time RT-PCR test system: 1 brain; 2 - lungs; 3 - kidneys; 4 lymphatic glands; 5 - hart; 6 - negative extraction control; 7 - negative PCR control; 8 - positive control (4 days after experimental infection).

The Akabane disease virus genome was detected in brain, lungs, kidney, lymphatic glands and hart of the animals from the group II (Fig. 2).

Thus, the developed test system based on real time RT-PCR allows detecting the Akabane disease virus genome in blood and organs of experimentally infected cavies. Therefore, these animals may serve a model in validation and approbation of the tests suggested for Akabane disease virus identification.

\section{RE F E R E N C ES}

1. Akulov A.V., Apate nko V.M., Arkhipov N.I. et. al. Patologoanatomicheskaya diagnostika boleznei krupnogo rogatogo skota [Anatomopathological diagnostics of cattle diseases]. Moscow, 1987.

2. B a la s h o v a E.A. Veterinariya, 2012, 10: 56-57.

3. $\mathrm{K}$ h a n E.O. Identifikatsiya virusa bolezni Akabane na osnove metodov analiza genoma. Kandidatskaya dissertatsiya [Identification of Akabane disease virus by means of genome analysis. PhD Thesis]. Pokrov, 2013.

4. M e t s e la a r D., R ob in Y. Akabane virus isolated in Kenya. Vet. Record., 1976, 99(5): 86 (PMID 982784) (doi: 10.1136/vr.99.5.86-a).

5. M urray M.D. Akabane epizootics in New South Wales: evidence for the long-distance dispersal of the biting midge Culicoides brevitarsis. Aust. Vet. J., 1987, 64(10): 305-308 (doi: 10.1111/j.1751-0813.1987.tb07332.x).

6. Syurin V.N., S a muile nko A.Ya., Solov'ev B.V., Fo mina N.V. Virusnye bolezni zhivotnykh [Viral diseases if animals]. Moscow, 1998. 
7. Matu moto M., In a b a Y. Akabane disease and Akabane virus. Kitasato Arch. Exp. Med., 1980, 53(1-2): 1-21 (PMID 6792415).

8. Doherty R.L., Carley J.G., S tandfast H.A., D y ce A.L., S nowdon W.A. Virus strains isolated from arthropods during an epizootic of bovine ephemeral fever in Queensland. Aust. Vet. J., 1972, 48(3): 81-86 (doi: 10.1111/j.1751-0813.1972.tb02220.x).

9. O mori T., I n a b a Y., Ku rog i H. et al. Viral abortion, arthrogryposis-hydranencephaly syndrome in cattle in Japan, 1972-1974. Bulletin de l'Office International des Epizooties, 1974, 81: 447-458.

10. $\mathrm{St}$ George T.D., Cybinski D.H., Paull N.I. The isolation of Akabane virus from a normal bull. Aust. Vet. J., 1977, 53(5): 249 (PMID 901328).

11. O e m J.K., L e e K.H., K i m H.R., B a e Y.C., Chung J.Y., Le e O.S., Roh I.S. Bovine epizootic encephalomyelitis caused by Akabane virus infection in Korea. J. Comp. Pathol., 2012, 147(2-3): 101-105 (doi: 10.1016/j.jcpa.2012.01.013). Epub 2012 Apr 19.

12. Jun Q., Q ingling M., Zaichao Z., Kuojun C., Jingsheng Z., M inxing M., $\mathrm{Chu}$ a $\mathrm{gfu}$ C. A serological survey of Akabane virus infection in cattle and sheep in northwest China. Trop. Anim. Health Prod., 2012, 44(8): 1817-1820 (doi: 10.1007/s11250-012-01683). Epub 2012 May 12.

13. Elh as san A.M., M a n sour M.E., $\mathrm{S} h$ a mon A.A., E $1 \mathrm{H}$ u s se in A.M. A serological survey of Akabane virus infection in cattle in Sudan. ISRN Vet Sci., 2014 (Jan 21): 123904 (doi: 10.1155/2014/123904).

14. O e m J.K., Y o on H.J., K i m H.R., R oh I.S., L e e K.H., L e e O.S., B a e Y.C. Genetic and pathogenic characterization of Akabane viruses isolated from cattle with encephalomyelitis in Korea. Vet. Microbiol., 2012, 158(3-4): 259-266 (doi: 10.1016/j.vetmic.2012.02.017). Epub 2012 Mar 1.

15. O e m J.K., K i m Y.H., K i m S.H., Le e M.H., Le e K.K. Serological characteristics of affected cattle during an outbreak of bovine enzootic encephalomyelitis caused by Akabane virus. Trop. Anim. Health Prod., 2014, 46(1): 261-263 (doi: 10.1007/s11250-013-0468-2). Epub 2013 Nov 16.

16. Tsutsui T., Yamamoto T., Hayama Y., Akiba Y., Nishiguchi A., Kobay a sh i S., Y a m a k a w M. Duration of maternally derived antibodies against Akabane virus in calves: survival analysis. J. Vet. Med. Sci., 2009, 71(7): 913-918 (doi: 10.1292/jvms.71.913).

17. K i m Y.H., K we on C.H., Tark D.S., Li m S.I., Y ang D.K., H y u n B.H., S ong J.Y., $\mathrm{Hu}$ r W., Park S.C. Development of inactivated trivalent vaccine for the teratogenic Aino, Akabane and Chuzan viruses. Biologicals, 2011, 39(3): 152-157 (doi: 10.1016/j.biologicals.2011.02.004). Epub 2011 Mar 21.

18. Hechinger S., Wernike K., Beer M. Evaluating the protective efficacy of a trivalent vaccine containing Akabane virus, Aino virus and Chuzan virus against Schmallenberg virus infection. Vet. Res., 2013, 44: 114 (doi: 10.1186/1297-9716-44-114).

19. Q ia o J., Wang J., Meng Q., Wang G., Liu Y., He Z., Yang H., Zhang Z., $\mathrm{Cai}$ X., Chen C. Rapid detection of Akabane virus by a novel reverse transcription loop-mediated isothermal amplification assay (RT-LAMP). Virol. J., 2013, 10: 288 (doi: $10.1186 / 1743-422 X-10-288)$.

20. Kittelberger R., McFadden A.M., Kirkland P.D., Hannah M.J., Orr D., Bueno R., Swainsbury R., Keen D., Jenner J., French J., Pigott C.J. Evaluation of two commercial enzyme-linked immunosorbent assay kits for the detection of serum antibodies against Akabane virus in cattle. J. Vet. Diagn. Invest., 2013, 25(5): 645-648 (doi: 10.1177/1040638713500496). Epub 2013 Aug 13.

21. B a las hova E.A. Razrabotka sredstv i metodov laboratornoi diagnostiki bolezni Akabane. Kandidatskaya dissertatsiya [Development of facilities and methods for laboratory diagnostics of Akabane disease. PhD Thesis. Pokrov, 1993]. Pokrov, 1993.

22. Zhabon E.O., Sal'nikov N.I., Balashova E.A., Selyaninov Yu.O. Materialy Mezhdunarodnoi konferentsii «Molekulyarnaya diagnostika-2010» [Proc. Int. Conf. «Molecular diagnostics-2010». V. 2]. Moscow, 2010, tom 2: 97-99.

23. Kolbasov D.V., Tsybanov S.Zh., Selyaninov Yu.O., Balashova E.A., Zhabon E.O., Sal'nikov N.I. Metodicheskie polozheniya po vyyavleniyu RNK virusa bolezni Akabane metodom polimeraznoi tsepnoi reaktsii [Methodical guidance on detection of Akabane disease virus RNA by PCR analysis]. Pokrov, 2011.

24. S yurin V.N., B elous ova R.V., S olov'ev B.V., Fom in a N.V. Metody laboratornoi diagnostiki virusnykh boleznei zhivotnykh [Laboratory diagnostics of viral diseases of animals]. Moscow, 1986. 